\title{
PERBEDAAN PRESTASI BELAJAR SISWA BERDASARKAN JENIS KELAMIN DAN TINGKAT PERHATIAN ORANG TUA DI KELAS XI MA SARJI AR-RASYID
}

\author{
Yesi Puspitasari ${ }^{1}$, Ahmad Hafas Rasyidi ${ }^{2}$, Irma Noervadila ${ }^{3}$ dan Nuril Firdausia ${ }^{4}$ \\ 1,2,3,4 STKIP PGRI Situbondo \\ Email : yesipuspita31@gmail.com
}

Received: July 15, $2021 \quad$ Revised: July 22, $2021 \quad$ Accepted: Augst 7, 2021

\begin{abstract}
ABSTRAK
Untuk mengetahui kemampuan pembelajaran matematik siswa maka dibutuhkan tingkat perhatian orang tua yang baik kepada anak, pengawasan belajar, pemenuhan kebutuhan belajar, pemberian bimbingan belajar, pemberian penghargaan, dan pemberian hukuman. Prestasi belajar juga dipengaruhi oleh jenis kelamin dan tingkat perhatian orang tua. Penelitian kuantitatif. Terdapat tiga variabel yaitu Jenis kelamin, Tingkat perhatian orang tua dan Prestasi Belajar. Data yang terkumpul dianalisis dengan statistik. Selanjutnya akan dilakukan uji validitas, kemudian di uji Reliabilitas untuk mengetahui instrumen yang reliabel, kemudian dilakukan uji Normalitas dan Uji Two Way Anova. Hasil data utama didokumentasi berupa nilai rapor matematika siswa semester sebelumnya, yaitu semester genap tahun ajaran 2020/2021. Banyaknya butir angket data tingkat perhatian orang tua 20 butir pernyataan. Setelah data angket diperoleh, data tersebut kemudian ditabulasi dalam sebuah tabel kemudian diuji validitas serta reliabilitasnya. Dengan banyaknya responden $=31(\mathrm{~N}=31)$, maka $\mathrm{r}_{\text {hitung }}=0,355$ dengan taraf signifikansi $5 \%$ atau 0,05. Angket tingkat perhatian orang tua, terdapat 5 butir angket tidak valid.Koefisien reliabilitas angket tingkat perhatian orang tua sebesar 0,765 yang berarti bahwa $\alpha>r_{\text {tabel }}$ atau 0,765>0,355 sehingga item angket tingkat perhatian orang tua dinyatakan reliabel. Dari hasil uji normalitas Kolmogorov-Smirnov diperoleh koefisien Sig. $>\alpha$ yaitu 0,200 > 0,05 sehingga data prestasi belajar matematika siswa dinyatakan berdistribusi normal. hasil anova dua arah (PerhatianOrangTua) diperoleh nilai probabilitas $F_{\text {hitung }}$ atau Sig. $=0,636<0,05$. Maka $\mathrm{H}_{0}$ diterima dan $\mathrm{H}_{\mathrm{a}}$ ditolak, JenisKelamin) diperoleh nilai probabilitas $F_{\text {hitung }}$ atau Sig. $=0.636>0,05$. Maka $\mathrm{H}_{0}$ ditolak dan $\mathrm{H}_{\mathrm{a}}$ diterima, (Perhatian Orang Tua/JenisKelamin) diperoleh nilai probabilitas $F_{\text {hitung }}$ atau Sig. = $0,347>0,05$. Maka $\mathrm{H}_{0}$ diterima dan $\mathrm{H}_{\mathrm{a}}$ ditolak yang menghasilkan kesimpulan tidak ada interaksi tingkat perhatian rang tua dan jenis kelamin dalam menentukan prestasi belajar matematika siswa.
\end{abstract}

Kata Kunci : Prestasi Belajar Siswa,Jenis Kelamin, Tingkat Perhatian Orang Tua 


\section{PENDAHULUAN}

Prestasi belajar sebagai produk akhir kegiatan belajar tidaklah diperoleh dengan cara dan prosedur sederhana. Namun, prestasi belajar menjadi gambaran menyeluruh dari kegiatan yang dilakukan siswa baik aktifitas mental dan spiritual (Wijayanti dan Harini, 2014).Faktor yang dapat mempengaruhi prestasi belajar siswa di antaranya adalah jenis kelamin dan tingkat perhatian orang tua. Menurut Danim (dalam Nurrahmah, 2015), Roger Sperry menyebutkan bahwa laki-laki dan perempuan memiliki perbedaan dalam cara berpikir. Karena adanya perbedaan tersebut, memungkinkan bahwa perolehan prestasi belajar juga akan berbeda.

MA Sarji Ar-Rasyid merupakan salah satu sekolah jenjang menengah pertama di Situbondo yang berada di bawah naungan pondok pesantren dan juga telah menerapkan kurikulum K13. Pada pembelajaran matematika kurikulum K13, siswa seharusnya terlibat secara aktif dalam proses pencarian dan penerimaan informasi. Termasuk dalam usaha untuk memotivasi keterlibatan siswa dalam pembelajaran adalah besarnya tingkat perhatian orang tua. Terlebih di dunia pesantren, siswa memiliki keterbatasan dalam berkomunikasi dengan orang tua sehingga kesempatan mereka untuk mendapatkan motivasi, dukungan, korongan, pengawasan, serta bimbingan dari orang tua sangat minim. Selain itu, perbedaan jenis kelamin juga turut memberikan kontribusi.

Jenis kelamin merupakan pembeda status kondisi fisik dan psikis individu manusia. Siswa laki-laki diidentifikasikan sebagai seorang yang lebih dapat mengontrol berbagai macam elemen kecerdasan emosi atau lebih stabil daripada siswa perempuan namun prestasi belajarnya lebih rendah daripada siswa laki-laki. Sedangkan siswa perempuan lebih banyak berprestasi daripada siswa laki-laki namun kurang bisa dalam hal mengontrol emosinya. Dengan demikian, jenis kelamin diasumsikan sebagai hal yang dapat mempengaruhi prestasi siswa (Safari dan Hestaliana R, 2019). Otak anak laki-laki lebih unggul daripada anak perempuan. Hal ini dikarenakan ada satu bagian dari otak yaitu IPL (inferior pariental lobule) pada anak laki-laki lebih besar terutama pada otak kirinya sehingga memungkinkan mereka untuk lebih unggul menguasai pengenalan ruang tiga dimensi (visual spatial). Dalam rentang usia 12-13 tahun, kemampuan matematika anak laki-laki lebih bagus daripada anak perempuan. 
Perhatian orang tua menjadi salah satu faktor penting dalam membimbing anak. Orang tua menjadi guru pertama dalam kehidupan dan guru adalah pengganti orang tua di sekolah. Orang tua sebagai guru pertama dalam kehidupan anak harus mampu memberikan perhatian khusus terhadap perkembangannya dalam segala aspek terutama pendidikan. Orang tua mempunyai peran penting untuk memberikan pengarahan kepada anak untuk lebih optimal dalam proses belajar di rumah. Adanya perhatian orang tua terhadap anak maka orang tua tidak kesulitan dalam mengarahkan keinginan anak, selain itu juga dapat menjalin ikatan batin orang tua dan anak semakin erat. Selain guru yang menggunakan model pembelajaran inovatif untuk menarik perhatian dan pemahaman anak, orang tua juga mempunyai peran penting dalam pendidikan anak. Orang tua mempunyai kewajiban sebagai guru di rumah dan memperhatikan perkembangan akademik anak (Koyimah, 2016).

\section{METODE PENELITIAN}

Metode digunakan dalam penelitian adalah penelitian kuantitatif (Sugiyono, 2016:30). Metode penelitian kuantitatif dipilih karena peneliti hendak menguji teori secara langsung di lapangan bersandarkan teori yang sebelumnya telah ada. Sementara itu, desain yang digunakan dalam penelitian ini adalah deskriptif kuantitatif. Penelitian dilaksanakan dengan menyebarkan angket perhatian orang tua terhadap siswa, kemudian mendokumentasi data prestasi belajar dari hasil nilai belajar matematika pada rapor siswa. Selanjutnya, data diolah dan dilakukan uji anova sebagai uji hipotesis. Uji anova dilakukan untuk mengetahui perbedaan prestasi belajar siswa berdasarkan jenis kelamin dan tingkat perhatian orang tua siswa. Kategori jenis kelamin dan tingkat perhatian orang tua dibagi menjadi 2 (dua) berdasarkan interval nilai yang siswa dapatkan pada rapor matematika. Teknik penentuan lokasi penelitian dilakukan MA Sarji Ar-Rasyid. Teknik penentuan responden penelitian dengan sebagai berikut;

1. Populasi dalam penelitian ini adalah seluruh siswa kelas XI di MA Sarji Ar-Rasyid

2. Teknik pengambilan sampel dalam penelitian ini adalah nonprobability sampling, yaitu pengambilan sampel dengan pusposive dan bersifat objektif dengan teknik purposive sampling (Indrawan \& Yaniawati, 
2014:105-106). Sampel dalam penelitian ini adalah siswa kelas XI di MA

Sarji Ar-Rasyid.

Teknik pengumpulan data meliputi; 1) observasi, 2) Angket (Kuesioner), 3) Dokumentasi. Teknik analisis data pada penelitian sebagai berikut;

1) Uji validitas dapat menggunakan rumus Korelasi Product Moment.

$$
r_{x y}=\frac{N\left(\sum X Y\right)-\left(\sum Y\right)\left(\sum^{Y}\right)}{\sqrt{\left\{N\left(\Sigma X^{2}\right)-(\Sigma X)^{2}\right\}\left\{N\left(\Sigma^{2}\right)-\left(\Sigma^{Y}\right)^{2}\right\}}} \quad \text { (Supandi dan Farikhah, 2016) }
$$

Keterangan:

$r_{x y}=$ Koefisien korelasi product moment

$\mathrm{N}=$ Jumlah objek

$\mathrm{X}=$ Skor butir item

$\mathrm{Y}=$ Skor total

Selanjutnya dihitung dengan Uji-t dengan rumus: $t_{\text {hitung }}=\frac{r \sqrt{n-2}}{\sqrt{1-r^{2}}}$

Di mana;

$$
\begin{aligned}
& \mathrm{t}=\text { Nilai } \mathrm{t}_{\text {hitung }} \\
& \mathrm{r}=\text { Koefisien korelasi hasil } \mathrm{r}_{\text {hitung }} \\
& \mathrm{n}=\text { Jumlah responden }
\end{aligned}
$$

Distribusi (Tabel t) untuk $\alpha=0,005$ dan derajat kebebasan $\{\mathrm{dk}=\mathrm{n}-2\}$

Kaidah keputusan; jika $t_{\text {hitung }}>t_{\text {tabel }}$ berarti valid $t_{\text {hitung }}<t_{\text {tabel }}$ berarti tidak valid

2) Uji reliabilitas item digunakan rumus Cronbach-Alpha, yaitu;

$$
r_{11}=\left[\frac{n}{(n-1)}\right]\left[1-\frac{\sum \chi_{i}^{2}}{s_{i}^{2}}\right] \quad(\text { Supandi dan Farikhah, 2016) }
$$

Keterangan:

$r_{11}=$ Reliabilitas instrumen

$n$ = Banyaknya butir pertanyaan

$\sum s_{i}^{2}=$ Jumlah varians skor tiap item

$s_{i}^{2}=$ Varians total

Sedangkan varians butir item dapat ditentukan dengan menggunakan formula;

$$
\sum s_{i}^{2}=\frac{\sum X^{2}-\frac{\left(\sum X\right)^{2}}{N}}{N}
$$

Keterangan: 
$\sum s_{i}^{2}=$ Jumlah varians skor tiap item

$\sum X^{2}=$ Jumlah skor butir item

$N=$ Jumlah objek

3) Uji normalitas menggunakan uji Kolmogorov-Smirnov untuk setiap data variabel penelitian pada taraf signifikansi $\alpha$ yang dipilih biasanya $\alpha=0,05$ (Indrawan dan Yaniawati, 2014:166).

Rumusan hipotesis:

$\mathrm{H}_{0}$ : Data berdistribusi normal

$\mathrm{H}_{\mathrm{a}}$ : Data tidak berdistribusi normal

Kriteria pengujian menggunakan SPSS dengan ketentuan:

Terima $\mathrm{H}_{0}$ : Data berdistribusi normal, jika nilai sig $\geq \alpha$

Terima $\mathrm{H}_{\mathrm{a}}$ : Data tidak berdistribusi normal, jika nilai sig $\leq \alpha$

4) Anova lebih dikenal dengan uji $\mathrm{F}$ (Fisher test), sedangkan arti variansi atau varians berasal dari pengertian konsep "Mean square" atau Kuadrat Rerata (KR). Rumusnya adalah:

$$
K R=\frac{J K}{d k}(\text { Riduwan \& Sunarto, 2017: 132) }
$$

Keterangan:

$\mathrm{JK}=\mathrm{Jumlah}$ kuadrat (some of square)

$\mathrm{Dk}=$ Derajat kebebasan (degree of freedom)

Menghitung nilai anova atau $\mathrm{F}_{\text {hitung }}$ dengan rumus;

$$
F_{\text {hitung }}=\frac{V_{A}}{V_{D}}=\frac{K R_{A}}{K R_{D}}=\frac{J K_{A}: d k_{A}}{J K_{D}: d k_{D}}=\frac{\text { Varians antar group }}{\text { Varians dalam group }}
$$

Varians Dalam Group dapat juga disebut Varians Kesalahan (Varians Galat). Lebih lanjut dapat dirumuskan;

$J K_{A}=\sum \frac{\left(\Sigma X_{A i}\right)^{2}}{n_{A i}}-\frac{\left(\Sigma X_{r}\right)^{2}}{N}$ untuk $\mathrm{dk}_{\mathrm{A}}=\mathrm{A}-1$

$J K_{D}=\Sigma X_{r}^{2}-\sum \frac{\left(\Sigma X_{A i}\right)^{2}}{n_{A i}}$ untuk $\mathrm{dk}_{\mathrm{D}}=\mathrm{N}-\mathrm{A}$

$\frac{\left(\Sigma X_{r}\right)^{2}}{N} \quad=$ sebagai faktor koreksi

$N=$ Jumlah keseluruhan sampel (jumlah kasus dalam penelitian)

$A \quad=$ Jumlah keseluruhan group sampel

Kaidah keputusan:

Jika $\mathrm{F}_{\text {hitung }}>\mathrm{F}_{\text {tabel}}$, maka $\mathrm{H}_{0}$ diterima dan $\mathrm{H}_{\mathrm{a}}$ ditolak 
Jika $\mathrm{F}_{\text {hitung }}<\mathrm{F}_{\text {tabel}}$, maka $\mathrm{H}_{0}$ ditolak dan $\mathrm{H}_{\mathrm{a}}$ diterima

\section{HASIL DAN PEMBAHASAN}

\section{Hasil}

\section{Uji validitas}

digunakan untuk menguji kevalidan data angket yang diperoleh setelah angket tersebut disebar dan diisi oleh responden. Dengan responden sebanyak 31 siswa, maka $\mathrm{N}=31$ dan taraf signifikansi $5 \%$ atau 0,05 sehingga $r_{\text {tabel }}=0,355$. Jika $r_{\text {hitung }}>r_{\text {tabel }}$ maka item dinyatakan valid dan jika $r_{\text {hitung }}<r_{\text {tabel }}$, maka item dinyatakan tidak valid.

Tabel Validitas Angket Tingkat Perhatian Orang Tua

\begin{tabular}{clccc}
\hline No & Item & $\mathbf{r}_{\text {hitung }}$ & $\mathbf{r}_{\text {tabel }}$ & Keputusan \\
\hline 1 & Pernyataan 1 & 0.390 & 0,355 & Valid \\
\hline 2 & Pernyataan 2 & 0.399 & 0,355 & Valid \\
\hline 3 & Pernyataan 3 & 0.379 & 0,355 & Valid \\
\hline 4 & Pernyataan 4 & 0.513 & 0,355 & Valid \\
\hline 5 & Pernyataan 5 & $\mathbf{0 . 2 5 8}$ & 0,355 & Tidak Valid \\
\hline 6 & Pernyataan 6 & 0.394 & 0,355 & Valid \\
\hline 7 & Pernyataan 7 & 0.504 & 0,355 & Valid \\
\hline 8 & Pernyataan 8 & $\mathbf{- 0 . 0 1 2}$ & 0,355 & Tidak Valid \\
\hline 9 & Pernyataan 9 & 0.377 & 0,355 & Valid \\
\hline 10 & Pernyataan 10 & 0.507 & 0,355 & Valid \\
\hline 11 & Pernyataan 11 & $\mathbf{0 . 0 3 0}$ & 0,355 & Tidak Valid \\
\hline 12 & Pernyataan 12 & 0.453 & 0,355 & Valid \\
\hline 13 & Pernyataan 13 & $\mathbf{0 . 2 1 6}$ & 0,355 & Tidak Valid \\
\hline 14 & Pernyataan 14 & $\mathbf{- 0 . 0 5 6}$ & 0,355 & Tidak Valid \\
\hline 15 & Pernyataan 15 & 0.524 & 0,355 & Valid \\
\hline 16 & Pernyataan 16 & 0.591 & 0,355 & Valid \\
\hline 17 & Pernyataan 17 & 0.372 & 0,355 & Valid \\
\hline 18 & Pernyataan 18 & 0.773 & 0,355 & Valid \\
\hline 19 & Pernyataan 19 & 0.437 & 0,355 & Valid \\
\hline 20 & Pernyataan 20 & 0.525 & 0,355 & Valid \\
\hline & & & & \\
\hline
\end{tabular}


Dari tabel dilihat bahwa dari 20 butir pernyataan, sebanyak 15 butir dinyatakan valid karena $r_{\text {hitung }}>r_{\text {tabel }}$ dan sebanyak 5 butir pernyataan dinyatakan tidak valid karena $r_{\text {hitung }}<r_{\text {tabel }}$.

\section{Uji Reliabilitas}

Dari hasil penghitungan SPSS Statistics 22 tersebut diperoleh Cronbach Alpha sebesar 0,765 yang berarti bahwa $\alpha>r_{\text {tabel }}$ atau 0,765>0,355 sehingga item angket tingkat perhatian orang tua dinyatakan reliabel.

\section{Uji Normalitas}

Bahwa variabel prestasi belajar matematika yang diambil dari data nilai rapor matematika semester ganjil pada bagian uji normalitas Kolmogorov-Smirnov menunjukkan koefisien Sig. $>\alpha$ yaitu 0,200 > 0,05 sehingga data prestasi belajar matematika siswa dinyatakan berdistribusi normal.

\section{Pengujian Hipotesis}

Dari output Descriptive Statistics dapat dilihat nilai rata-rata (Mean) prestasi belajar matematika siswa berdasarkan tingkat perhatian orang tua dan jenis kelamin. Nilai rata-rata (Mean) prestasi belajar matematika siswa dengan tingkat perhatian orang tua rendah dengan jenis kelamin laki-laki sebesar 78,25 dan perempuan sebesar 77,50 sehingga total rata-rata keduanya sebesar 77,87, Nilai rata-rata (Mean) prestasi belajar matematika siswa dengan tingkat perhatian orang tua tinggi dengan jenis kelamin laki-laki sebesar 78,00 dan dan perempuan sebesar 78,25 sehingga total rata-rata keduanya sebesar 78,13. Total nilai rata-rata (Mean) prestasi belajar matematika siswa berdasarkan tingkat perhatian orang tua rendah dengan jenis kelamin laki-laki adalah 78,13 dan berdasarkan tingkat perhatian orang tua tinggi dengan jenis kelamin perempuan adalah 77,87 sehingga total keduanya adalah 78,00.

Output Tests of Between-Subjects Effects di atas berfungsi untuk menjawab rumusan masalah dan digunakan sebagai uji hipotesis anova dua arah sebagai berikut;

1. Pengujian hipotesis 1 (tingkat perhatian orang tua)

Berdasarkan hasil anova dua arah pada tabel di atas yaitu baris ke-3 (PerhatianOrangTua) diperoleh nilai probabilitas $F_{\text {hitung }}$ atau Sig. $=0,636>$ 0,05 . 
2. Pengujian hipotesis 2 (jenis kelamin)

Berdasarkan hasil anova dua arah pada tabel di atas yaitu baris ke-4 (JenisKelamin) diperoleh nilai probabilitas $F_{\text {hitung }}$ atau Sig. $=0,636>0,05$.

3. Pengujian hipotesis interaksi

Berdasarkan hasil anova dua arah pada tabel di atas yaitu baris ke-5

(PerhatianOrangTua*JenisKelamin) diperoleh nilai probabilitas $F_{\text {hitung }}$ atau Sig. $=0,347>0,05$.

\section{Pembahasan}

Penelitian dilakukan terhadap siswa kelas X MA Sarji Ar-Rasyid semester Ganjil tahun pelajaran 2020/2021. Jumlah keseluruhan siswa sebanyak 31 orang dengan rincian siswa perempuan sebanyak 16 orang dan siswa laki-laki sebanyak 15 orang. Data utama diperoleh dengan teknik angket untuk variabel tingkat pernhatian orang tua dan teknik dokumentasi untuk variabel prestasi belajar matematika. Data yang didokumentasi berupa nilai rapor matematika siswa semester sebelumnya, yaitu semester genap tahun ajaran 2020/2021.

Banyaknya butir angket data tingkat perhatian orang tua 20 butir pernyataan. Setelah data angket diperoleh, data kemudian ditabulasi dalam sebuah tabel kemudian diuji validitas serta reliabilitasnya. Dengan banyaknya responden = $31(\mathrm{~N}=31)$, maka $\mathrm{r}_{\text {hitung }}=0,355$ dengan taraf signifikansi $5 \%$ atau 0,05 .

Koefisien reliabilitas angket tingkat perhatian orang tua sebesar 0,765 yang berarti bahwa $\alpha>r_{\text {tabel }}$ atau 0,765>0,355 sehingga item angket tingkat perhatian orang tua dinyatakan reliabel. Dari data angket tingkat perhatian orang tua dan klasifikasi jenis kelamin, kemudian dibagi menjadi 2 aspek yaitu tingkat perhatian orang tua rendah dan tinggi, serta jenis kelamin lakilaki dan perempuan. Tahap uji selanjutnya adalah menguji normalitas data prestasi belajar sebagai syarat mutlak untuk melakukan uji parametrik anova dua arah. Dari hasil uji normalitas Kolmogorov-Smirnov diperoleh koefisien Sig. $>\alpha$ yaitu $0,200>0,05$ sehingga data prestasi belajar matematika siswa dinyatakan berdistribusi normal.

Hasil dari uji hipotesis menggunakan uji anova dua arah dibantu dengan perangkat lunak SPSS Statistics 22 tertera pada Tabel 4.16 adalah; 
1. Pengujian hipotesis 1

Hasil anova dua arah pada Tabel 4.16 yaitu baris ke-3 (PerhatianOrangTua) diperoleh nilai probabilitas $F_{\text {hitung }}$ atau Sig. $=0,636<$ 0,05. Maka $\mathrm{H}_{0}$ diterima dan $\mathrm{H}_{\mathrm{a}}$ ditolak. Sehingga dapat disimpulkan bahwa tidak ada ada perbedaan prestasi belajar matematika siswa berdasarkan tingkat perhatian orang tua.

Berdasarkan pengamatan yang telah dilakukan, tidak adanya perbedaan tersebut dapat disebabkan karena kondisi siswa yang bermukim di pondok sehingga interaksi antara siswa dengan orang tua sangat minim. Mimimnya interaksi juga menyebabkan kurangnya perhatian orang tua kepada siswa dalam hal belajar sehingga berdampak pada prestasi belajar mereka.

2. Pengujian hipotesis 2

Hasil anova dua arah pada Tabel 4.16 yaitu baris ke-4 (JenisKelamin) diperoleh nilai probabilitas $F_{\text {hitung }}$ atau Sig. $=0.636>0,05$. Maka $\mathrm{H}_{0}$ ditolak dan $\mathrm{H}_{\mathrm{a}}$ diterima. Sehingga dapat disimpulkan bahwa tidak ada perbedaan prestasi belajar matematika siswa berdasarkan jenis kelamin.

Hasil tersebut dapat dijelaskan penyebab atau faktornya, yaitu karena di dalam lingkungan pondok semua siswa mendapat perlakuan yang sama dan sangat terbatas, misalnya dalam hal belajar yang terkadang bentrok dengan kegiatan pondok. Antara laki-laki dan perempuan memiliki jadwal terbatas yang sama, hanya mungkin berbeda waktu pelaksanaan. Yang mana apabila siswa tidak bermukim di pondok, maka perlakuan yang mereka dapatkan yang membatasi gender tidak akan sama.

3. Pengujian hipotesis 3

Hasil anova dua arah pada Tabel 4.16 yaitu baris ke-5 (PerhatianOrangTua*JenisKelamin) diperoleh nilai probabilitas $\mathrm{F}_{\text {hitung }}$ atau Sig. $=0,347>0,05$. Maka $\mathrm{H}_{0}$ diterima dan $\mathrm{H}_{\mathrm{a}}$ ditolak yang menghasilkan kesimpulan tidak ada interaksi tingkat perhatian rang tua dan jenis kelamin dalam menentukan prestasi belajar matematika siswa.

Besarnya kombinasi nilai variabel independen secara simultan atau bersamasama mempengaruhi nilai variabel dependen, atau disebut juga nilai 
determinasi berganda semua variabel independen dengan dependen dapat dilihat dari besarnya R Squared. Dari tabel di atas, diperoleh $\mathrm{R}$ Squared = 0,050 berarti bahwa variabel tingkat perhatian orang tua dan jenis kelamin secara bersama-sama mempengaruhi prestasi belajar matematika siswa sebesar $5 \%$.

\section{Kesimpulan}

Dari penelitian diatas peneliti menarik kesimpulan bahwa;

1. Tidak ada perbedaan prestasi belajar matematika siswa tingkat perhatian orang tua di kelas X MA Sarji Ar-Rasyid.

2. Tidak ada perbedaan prestasi belajar matematika siswa berdasarkan jenis kelamin di kelas X MA Sarji Ar-Rasyid.

3. Tidak ada interaksi tingkat perhatian orang tua dan jenis kelamin dalam menentukan prestasi belajar matematika siswa di kelas X MA Sarji ArRasyid.

\section{DAFTAR PUSTAKA}

Arumsari, D. (2017). Pengaruh Media Pembelajaran dan Keterampilan Pengelolaan Kelas terhadap Prestasi Belajar Siswa SMK Negeri 5 Madiun

Astuti, A., dan Leonard. (2015). Peran Kemampuan Komunikasi Matematika terhadap Prestasi Belajar Matematika Siswa. Jurnal Formatif, 2(2), 102-110

Cleopatra, M. (2015). Pengaruh Gaya Hidup dan Motivasi Belajar terhadap Prestasi Belajar Matematika. Jurnal Formatif 5(2).

Endriani, A. (2016). Hubungan Perhatian Orang Tua dengan Motivasi Belajar pada Siswa Kelas VIII SMPN 6 Praya Timur Lombok Tengah Tahun Pelajaran 2015/2016.

Hamdu, G., dan Agustina, L. 2011. Pengaruh Motivasi Belajar Siswa terhadap Prestasi Belajar IPA di Sekolah Dasar (Studi Kasus terhadap Siswa Kelas IV SDN Tarumanagara Kecamatan Tawang Kota Tasikmalaya).

Hendriani, Y. dan Muchtar, B. Pengaruh Perhatian Orang Tua dan Konsep Diri terhadap Prestasi Belajar Siswa Mata Pelajaran Produktif Akuntansi pada SMK di Kota Payakumbuh.

Indrawan, R., dan Yaniawati, P. (2014). Metodologi Penelitian Kuantitatif, Kualitatif, dan Campuran untuk Manajemen, Pembengunan, dan Pendidikan (N. F. Atif (ed.)). PT Refika Aditama.

Mulyaningsih, I. E. 2014. Pengaruh Interaksi Sosial Keluarga, Motivasi Belajar, dan Kemandirian Belajar terhadap Prestasi Belajar

Nurrahmah, F. (2015). Profil Proses Berpikir Kreatif Siswa Kelas X menurut Wallas dalam Memecahkan Masalah pada Materi Pokok Gerak Lurus Ditinjau dari Jenis Kelamin dan Prestasi Belajar Fisika (Studi Deskriptif Analitis Siswa Kelas X MAN 1 Sragen Tahun Ajaran 2014/2015).

Perbangsa, W. W. A., dan Haq, C. N., (2014). Perbedaan Prestasi Belajar Matematika Siswa antara yang Mendapatkan Model Pembelajaran Guided 
Note Taking dengan Team Accelerated Instruction. Jurnal Pendidikan Matematika, 3(3)

Riduwan, dan Sunarto, H. (2017). Pengantar Statistika untuk Penelitian Pendidikan, Sosial, Ekonomi, dan Bisnis (H. Akdon (ed.)). Penerbit Alfabeta.

Rohmah, E. N. (2017). Pengaruh Tingkat Pendapatan dan Perhatian Orang Tua terhadap Hasil Belajar IPS Kelas V SDN Gugus Putra Serang 2 Wonosegoro Boyolali.

Sirait, E. D. (2016). Pengaruh Minat Belajar terhadap Prestasi Belajar Matematika. Jurnal Formatif, 6(1), 35-43.

Sugiyono. (2015). Metode Penelitian Kuantitatif, Kualitatif, dan RdanD. Penerbit Alfabeta.

Sugiyono. (2016). Metode Penelitian Kuantitatif, Kualitatif, dan RdanD. Penerbit Alfabeta.

Sugiyono. (2017). Metode Penelitian Kuantitatif, Kualitatif, dan RdanD. Penerbit Alfabeta.

Sumiyati, T., Amri, B., dan Sukayasa. (2017). Pengaruh Perhatian Orang Tua, Konsep Diri dan Motivasi Belajar terhadap Hasil Belajar Siswa tentang Matematika Kelas VIII SMP Negeri di Kecamatan Sausu Kabupaten Parigi Moutong.

Supandi, S., dan Farikhah, L. (2016). Analisis Butir Soal Matematika Pada Instrumen Uji Coba Materi Segitiga. JIPMat, 1(1), 71-78. https://doi.org/10.26877/jipmat.v1i1.1085

Vandini, I. (2015). Peran Kepercayaan Diri terhadap Prestasi Belajar Matematika Siswa. Jurnal Formatif 5(3).

Wijayanti, T. S., dan Harini, E., (2014). Meningkatkan Minat dan Prestasi Belajar Matematika dengan Model Pembelajaran Group Investigation Siswa Kelas VII A SMP Negeri 1 Polanharjo Klaten. Union: Jurnal Pendidikan Matematika, 2(1). 
